https://doi.org/10.15407/scine17.02.105

BOIARYNOVA, K. O. (https://orcid.org/0000-0001-5879-2213),

and KOPISHYNSKA, K. O. (https://orcid.org/0000-0002-1609-2902),

National Technical University "Igor Sikorsky Kyiv Polytechnic Institute",

37, Peremohy Ave., Kyiv, 03056, Ukraine,

+380 44236 7989, mail@kpi.ua

\title{
ANALYSIS OF LOGISTICS STARTUPS DEVELOPMENT IN THE EU COUNTRIES AND UKRAINE
}

Introduction. Accelerating technological development is a driving force of innovative entrepreneurship in all areas. Young and creative people offer to the market their non-standard solutions in the form of startup projects. Currently, the development of a startup ecosystem reflects country's interest in and promotion of new technologies.

Problem Statement. The efficiency of transport and logistics activities reflects the development of the infrastructure of a country as a whole and significantly affects the efficiency of economic activities. The development and implementation of logistics startups, given the experience of advanced economies, may help find solutions to certain problems of industry and its further development.

Purpose. The purpose is to analyze the market of logistics startups of the EU Member States and Ukraine, to determine the directions of its further development.

Materials and Methods. In the research, general and special methods have been used: analysis and synthesis for determining the sectoral structure of formation and development of startups in the EU and Ukraine; correlation analysis for establishing the dependence between the indicators of development of startup ecosystems and indices of logistic activity of countries, grouping for distributing logistic startups of the EU and Ukraine countries by clusters; graphical method for designing a roadmap for logistics startup development.

Results. The current sectoral structure of the EU and Ukrainian startups has been researched, the share of transport and logistics projects has been determined. The EU and Ukraine rankings in terms of the indicators of the development of startup ecosystems and logistic activity have been analyzed. The correlation analysis has shown a sufficiently close relationship between countries' ratings of startup ecosystems and logistics activity. The main logistics startups of the EU and Ukrainian countries are grouped in certain clusters of logistics startups. A roadmap for the development of logistics and transport startups for the EU and Ukraine has been proposed.

Conclusions. To date, logistics startups are not among the priorities for the market development in the EU and Ukraine. However, logistical activity in the country may be not only one of the areas where startups are developed, but also a part to the infrastructure of the startup ecosystem. Both the EU Member States and Ukraine are expected to develop startups in high-tech clusters in the future.

Keywords: startups, logistics startups, Logistics Performance Index, Startup Ecosystem, cluster, and roadmap..

Citation: Boiarynova, K. O., and Kopishynska, K. O. Analysis of Logistics Startups Development in the EU Countries and Ukraine. Sci. innov. 2021. V. 17, no. 2. P. 105-116. https://doi.org/10.15407/scine17.02.105 
Digital innovations continue changing the world. Digitalization has penetrated all business environments, starting with production and ending with logistics. Automation, robotics, the Internet of Things, cloud storage, virtual warehouses, RFIDtechnologies, and the use of drones to deliver goods are an incomplete list of key ICT advancements that already have been being used in the logistics activities of companies around the world. The active spread of the Internet in the world has given a significant impetus to the development of e-commerce, which, in turn, has stimulated the development of transport and logistics networks. Ukraine being sufficiently integrated into the world economic system, especially after the signature of the Association Agreement with the European Union, these global trends have inevitably affected its business environment. Recently, the development of startup ecosystems and the rise in the number of startups have become major indicators of ICT implementation and development in different countries. In terms of this indicator, Ukraine has been also showing a significant improvement.

Both Ukrainian and foreign researchers and analysts have dealt with study and analysis of the peculiarities of startup development. The issues of operation, financing, and development of logistics startups in EU Member States have received considerable attention in by A. Sword [1] and O. Wyman [2]. The prospects for the logistics startup market in general, and in the US in particular, have been considered by S. Wengler and Ph. Biermann [3]. The vast majority of domestic research on startup projects concerns the nature and features of the market as a whole. Thus, D. Khromova and K. Antonenko have analyzed the global trends in the development of the startups market [4], while R. Babiachok and I. Kulchytsky have studied the problems and prospects of development of the startup market in Ukraine [5]. An analysis of the investment support of startups in Ukraine at different stages of their life cycle has been also presented [6]. However, in the scholarly research literature, there is practically neither a clear definition of the key sectoral directions for the development of startup projects in Ukraine, in particular, for logistics startups, nor comparison of such projects with those in the EU Member States.

The purpose of the study is to systematically analyze the Ukrainian startup market, the EU market, to compare key positions of the logistic startup projects of Ukraine and the EU, as well as to identify key areas for the development of logistics startup projects.

There are many approaches to define the term "startup". In the article, the authors understand startup as a temporary structure that creates a new original product in conditions of high competition and uncertainty aimed at finding and implementing a scalable business model [7, 8]. Europe's startup market has been developing very quickly: the number of startups has tripled within 20162018 [9]. Early-stage startups are better financed than ever before. Investment in European tech is record high, with USD 23 billion invested in 2018, a five-year increase by $360 \%$ and an increase by $21 \%$ as compared with 2017 . However, fragmentation on European markets seems to put Europe at a structural disadvantage. Large and more homogeneous markets in the United States and China ease fast scale-up and create instant demand from tech-enthusiastic consumers [10].

European industrial companies could build on its collaboration to foster cooperation across industry boundaries and even among competing companies in the same industrial sectors. Examples set by the European Automotive and Telecoms Alliance, which includes telecom operators, vendors, car and truck manufacturers, and suppliers, may be only the beginning, as competitors in the automobile industry combine their research efforts and service offerings to achieve more scale in customer and data access. Such efforts in other sectors could enable medium-size companies as well as small entrepreneurial firms and startups to pilot innovation at a large scale within existing industrial supply chains through platforms and to play a key role in generating radical 


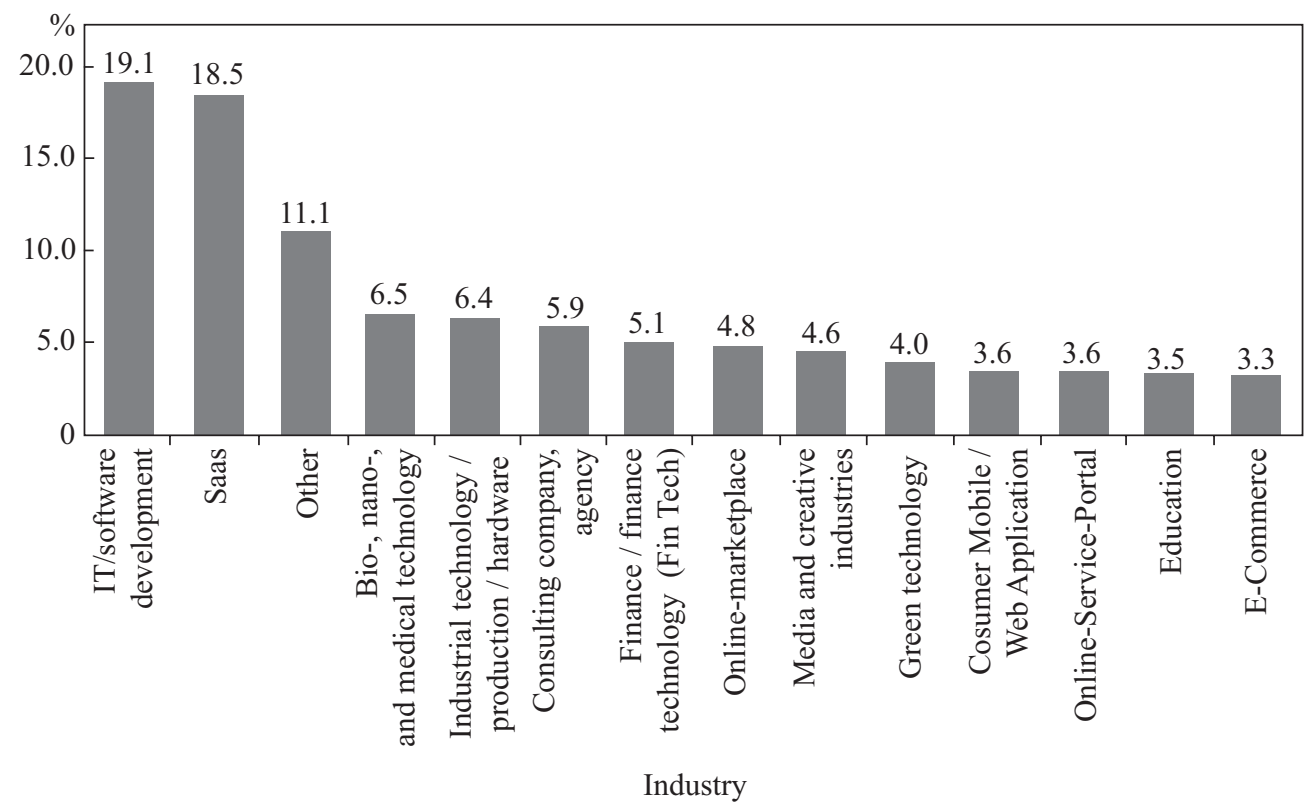

Fig. 1. Startup sectors in the EU in $2018, \%$ Source: [13].

innovation [11]. In this case, startups in logistics and transportation may become the most important connecting link between industrial companies and foster their competitiveness in both local and global markets.

Platform technology has given rise to new business models, often driven by startups that enter the logistics industry. New 'sharing' business models could have as much of an impact on the sector as new technology. And the industry's current customers and suppliers may end up being the biggest new entrants. Venture capital flows into digital logistics startups since 2011 consists of Private equity flows more than USD 150 million and Flows from legacy logistics companies less than USD 10 million [12].

The sectors that the EU startups are active in are very diverse. While sectors such as IT/Software development (19.1\%) or Software as a Service $(18.5 \%)$ are still well-represented, new companies have also been created in trending sectors such as Green technologies (4.0\%) and in the Fin-Tech sector (5.1\%) (Fig. 1).

The transport and logistics sector is not one of the key areas for startups in the EU today. How- ever, there are some European startups that are already working to transform the logistics sector [1]:

- Vekia - predictive analytics for the supply chain (London, UK); The software can provide daily forecasts of potential sales, combined with calculations of what level of stock is required to cover these. The tool is also able to automatically calculate the most profitable orders to number of orders to make from suppliers, depending on factors such as discounted delivery for bulk orders;

- Magazino - robotics for the warehouse (Munich, Germany); Equipped with cameras, the robots are able to stow and pick up individual items as well as pallets or crates. They are designed to be used alongside existing human workers, with the ability to sense when humans want to cross their path;

- Glovo - last mile with a twist (Barcelona, Spain); Built around the Glovo app, the company consists of a network of independent couriers called Glovers. The customer orders a product from any shop or restaurant, with the Glover traveling to the store, purchasing the goods and then shipping them to the customer; 


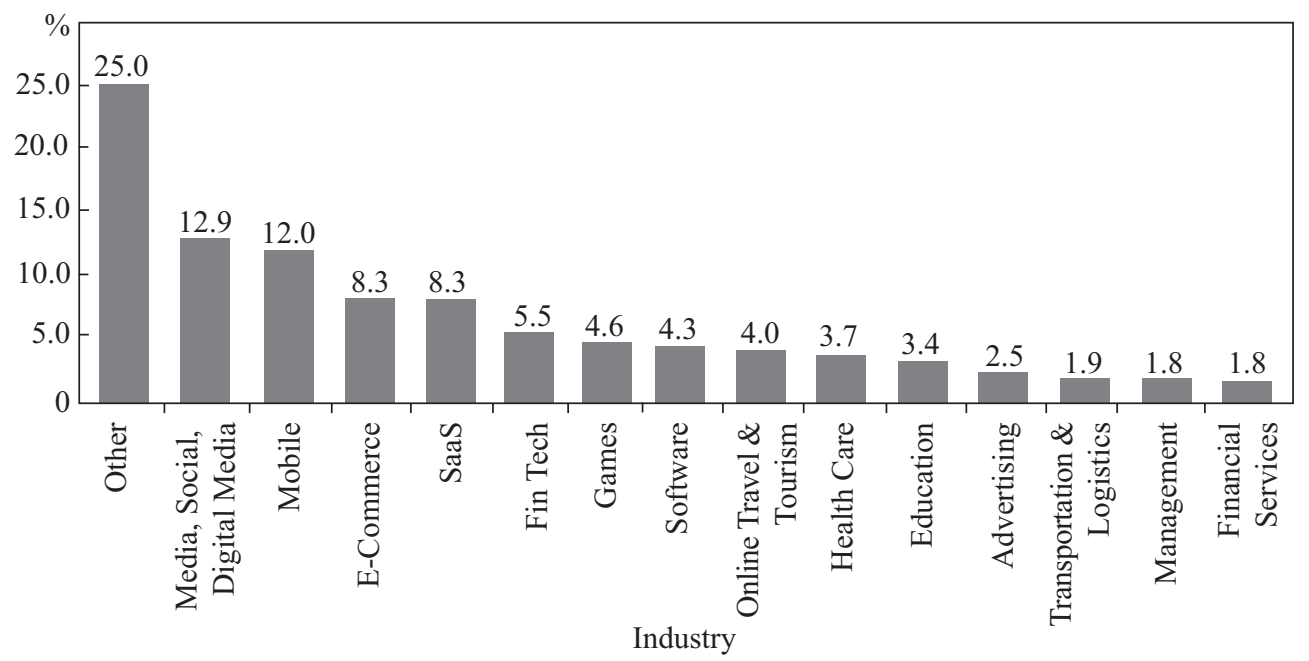

Fig. 2. Startup sectors in Ukraine in 2019, \%

Source: calculated by the authors according to the data [15].

- Cleveron - collection and returns (Tallinn, Estonia); Estonia's Cleveron aims to fully automate fulfillment. Its flagship solution, the $\mathrm{Cle}$ veron 401, allows customers to both collect and return parcels. It also offers a self-driving robot, currently in the prototype stage, will be able to ferry a package from a local distribution center and place them in a personal parcel locker at a customer's home;

- Quicargo - an Airbnb sharing model for logistics (Amsterdam, the Netherlands). Quicargo software application allows businesses moving goods to search in real time for empty lorries, promising up to $30 \%$ reductions in freight costs. It includes a matching and pricing algorithm, track and trace options and payment solutions. A startup project that can significantly change existing transport logistics paradigms is Swedish Einride, which offers a complete Autonomous Electric Transport (AET) solution consisting of an intelligent shipping platform and electrically powered, driverless Einride Pods. Einride Pods are autonomous, all-electric transport vehicles equipped with specialized modular trailers for pallets, timber, perishable goods, and anything else one needs to ship [14].

Consider in more detail the structure of startup projects in Ukraine. StartupBlink, a Global Map of Startup Ecosystems, ranks Ukraine at 31 positions among 100 countries according to their startup ecosystem strength in 2019. Ukraine has improved its Startup Ecosystem since 2017 and moved up for 4 points in the Countries Global Ranking.

As can be seen from the Fig. 2, the top 5 sectors in which startups are most actively developed include: Media; Social, Digital Media (12.9\%), Mobile (12.0\%), E-Commerce (8.3\%), SaaS (8.3\%) and Fin Tech (5.5\%). Only about $2 \%$ of the total number of registered in Ukraine startup projects belong to the sphere of Logistics and Transportation. Among them, it is worth highlighting the following startup projects: Cargofy (a virtual assistant that automates manual logistics in artificial intelligence) and CargoStock (an online service that helps cargo owners find carriers and help carriers find shipping orders at the same time).

Over the past couple of years, 53 European logistics-related startups received more than EUR160 million worth of venture capital between them [16]. At the same time, more than USD 1.5 billion were invested in core logistics startup segments in the USA in 2017 [3]. The United States are leaders of the startups market, their projects are the most popular and the most expensive [4]. Thus, the investment in logistics 
startups in the USA in one year is almost ten times greater than investing in such projects in Europe in a few years.

One of the problems of startups development in Ukraine is lack of investments [5]. According to [6], the total startup investment in Ukraine in 2017 is about USD 265 million. In Ukraine, the share of logistics startups in total investment in such projects does not exceed USD 5.3 million. This figure is very small as compared with investment in the United States. However, it is comparable to individual EU Member State's investment into logistics startups.

In order to compare the strength of logistics industry in Ukraine and the EU countries, it is appropriate to use the Logistics Performance Index (LPI). It is based on the survey of operators on the ground (global freight forwarders and express carriers), providing feedback on the logistics "friendliness" of the countries in which they operate and those with which they trade (Fig. 3) [5].

According to the data, presented at Fig. 3, Ukraine has a low LPI Score as compared with the EU countries. Only two countries, Malta and Latvia, showed worse results in Logistics performance than Ukraine. While eight of the top ten countries with the best results in the world are the EU members, the average EU LPI corresponds to the country ranked at the $28^{\text {th }}$ position, which is more than twice better than the position of Ukraine in this rating.

Concerning the performance of startup ecosystems in the EU and Ukraine, here is a somewhat different situation (Fig. 4). StartupBlink ranks 100 countries and more than 1000 cities according to their startup ecosystem strength. By indicator of startup ecosystem development, Ukraine is showing a result that is almost in line with the EU average. However, overall trends in most advanced economies persist, and the countries with a high LPI score generally also have a well-developed startup ecosystem.

For the convenience of comparison, we will present country ratings by indicators Startup Ecosystem Score and LPI in Table 1.
Table 1. LPI and Startup Ecosystem Rank and Score for the EU and Ukraine

\begin{tabular}{|c|c|c|c|c|c|}
\hline Country & $\begin{array}{c}\text { LPI } \\
\text { Rank }\end{array}$ & $\begin{array}{c}\text { LPI } \\
\text { Score } \\
\text { ascen- } \\
\text { ding }\end{array}$ & Country & $\begin{array}{c}\text { Startup } \\
\text { Eco- } \\
\text { system } \\
\text { Rank }\end{array}$ & $\begin{array}{c}\text { Startup } \\
\text { Ecosystem } \\
\text { Score } \\
\text { ascending }\end{array}$ \\
\hline Germany & 1 & 4.2 & $\begin{array}{l}\text { United } \\
\text { Kingdom }\end{array}$ & 2 & 16.71 \\
\hline Sweden & 2 & 4.05 & $\begin{array}{c}\text { Nether- } \\
\text { lands }\end{array}$ & 6 & 12.90 \\
\hline Belgium & 3 & 4.04 & Sweden & 7 & 12.77 \\
\hline Austria & 4 & 4.03 & Germany & 9 & 12.46 \\
\hline $\begin{array}{l}\text { Nether- } \\
\text { lands }\end{array}$ & 6 & 4.02 & Spain & 10 & 12.39 \\
\hline Denmark & 8 & 3.99 & France & 11 & 11.45 \\
\hline $\begin{array}{l}\text { United } \\
\text { Kingdom }\end{array}$ & 9 & 3.99 & Finland & 12 & 11.36 \\
\hline Finland & 10 & 3.97 & Estonia & 13 & 11.26 \\
\hline France & 16 & 3.84 & Ireland & 14 & 11.11 \\
\hline Spain & 17 & 3.83 & Denmark & 16 & 10.65 \\
\hline Italy & 19 & 3.74 & Lithuania & 18 & 10.52 \\
\hline $\begin{array}{l}\text { Czech } \\
\text { Republic }\end{array}$ & 22 & 3.68 & Poland & 20 & 10.44 \\
\hline Portugal & 23 & 3.64 & $\begin{array}{c}\text { Czech } \\
\text { Republic }\end{array}$ & 22 & 10.16 \\
\hline $\begin{array}{l}\text { Luxem - } \\
\text { bourg }\end{array}$ & 24 & 3.63 & Belgium & 24 & 10.08 \\
\hline Poland & 28 & 3.54 & Italy & 25 & 10.06 \\
\hline Ireland & 29 & 3.51 & Austria & 28 & 10.04 \\
\hline Hungary & 31 & 3.42 & Portugal & 29 & 10.03 \\
\hline Slovenia & 35 & 3.31 & Ukraine & 31 & 9.72 \\
\hline Estonia & 36 & 3.31 & Bulgaria & 35 & 9.26 \\
\hline Greece & 42 & 3.2 & Romania & 38 & 9.21 \\
\hline Cyprus & 45 & 3.15 & Hungary & 39 & 9.18 \\
\hline Romania & 48 & 3.12 & Greece & 42 & 8.82 \\
\hline Croatia & 49 & 3.1 & Latvia & 45 & 8.47 \\
\hline Bulgaria & 52 & 3.03 & Slovenia & 48 & 7.91 \\
\hline Slovakia & 53 & 3.03 & Slovakia & 49 & 7.80 \\
\hline Lithuania & 54 & 3.02 & Croatia & 50 & 7.56 \\
\hline Ukraine & 66 & 2.83 & $\begin{array}{l}\text { Luxem- } \\
\text { bourg }\end{array}$ & 53 & 6.98 \\
\hline Malta & 69 & 2.81 & Cyprus & 68 & 4.38 \\
\hline Latvia & 70 & 2.81 & Malta & 89 & 2.06 \\
\hline $\mathrm{EU}$ & $\begin{array}{c}28 \\
\text { (average } \\
\text { value) }\end{array}$ & $\begin{array}{c}3.54 \\
\text { (average } \\
\text { value) }\end{array}$ & $\mathrm{EU}$ & $\begin{array}{c}31 \\
\text { (average } \\
\text { value) }\end{array}$ & $\begin{array}{c}9.85 \\
\text { (average } \\
\text { value) }\end{array}$ \\
\hline
\end{tabular}

Source: calculated by the authors according to the data $[11,15]$. 


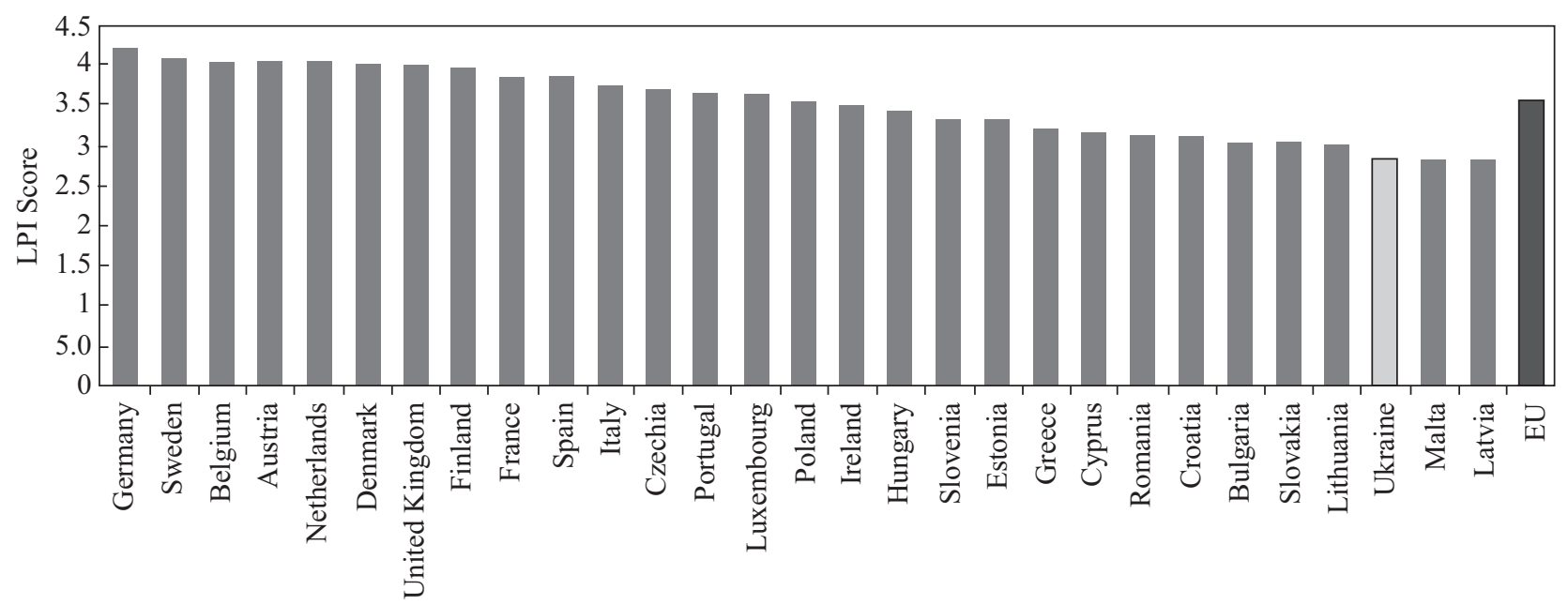

Fig. 3. LPI Score of the EU countries and Ukraine in 2018

Source: calculated by the authors according to the data [17].

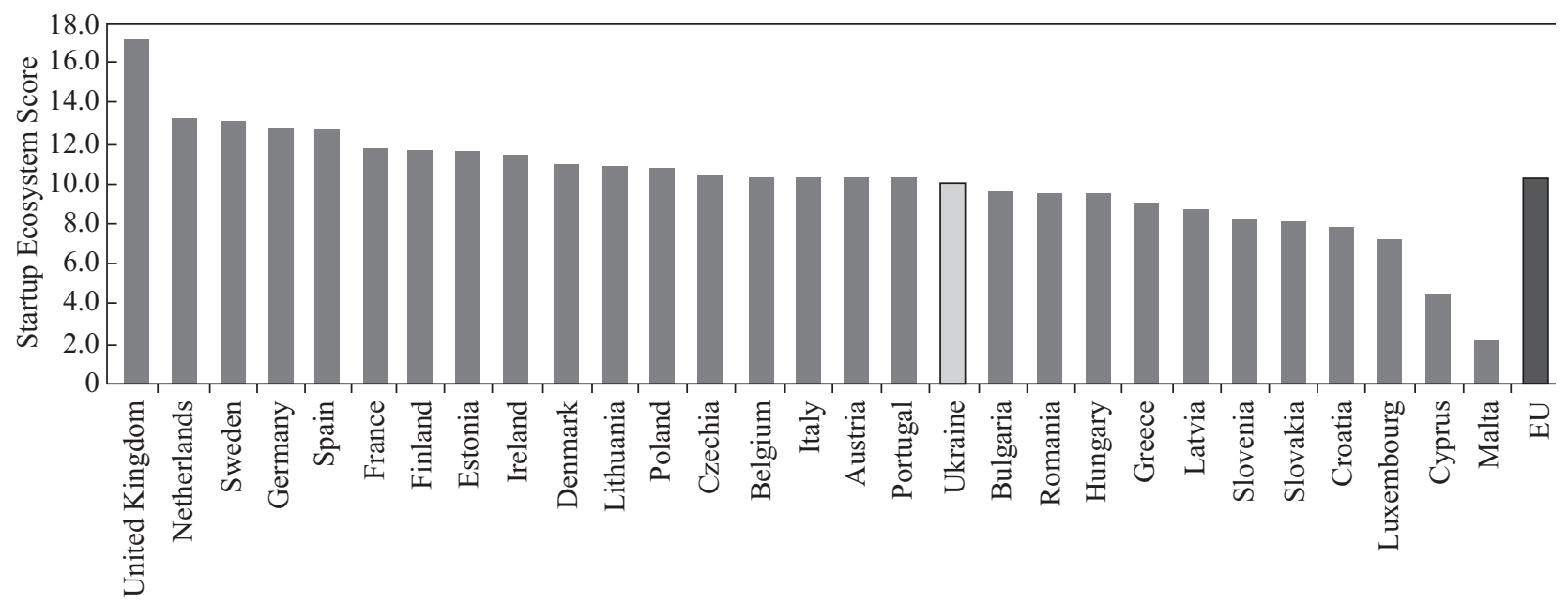

Fig. 4. Startup Ecosystem Score of the EU countries and Ukraine in 2019

Source: calculated by the authors according to the data [15].

Determine whether there is a relationship between the logistics performance in the country and the development of its startup ecosystem. To do this, we determine the correlation between the indicators LPI Score and Startup Ecosystem Score for the EU countries and Ukraine (Tables 2,3). The mathematical measure of the correlation of two random variables is the correlation coefficient, which is a relative measure of the relationship between the two traits, so it can take values from -1 to +1 . The closer the value of $r$ is to \pm 1 , the denser the bond.
The criterion for the homogeneity of the information is the standard deviation and the coefficient of variation, which are calculated for each indicator. Using the coefficient of variation, even fluctuations in the characteristics expressed in different units can be compared. The coefficient of variation can vary from 0 to $100 \%$. The greater the coefficient is, the greater the fluctuations are. The following coefficients of variation have been estimated as: up to $10 \%$ (weak fluctuations); $10-25 \%$ (moderate fluctuation); $25-33 \%$ (significant fluctuation), if it is greater 
than 33\% indicates heterogeneity of information [18].

Therefore, according to the results obtained (Table 3), the coefficient of variation for is within the range of moderate fluctuations, for the LPI

Table 2. Estimated data to determine

the correlation between LPI and Startup Ecosystem

\begin{tabular}{|l|c|c|c|c|r|r|}
\hline Country & $\begin{array}{c}\text { LPI } \\
\text { Score } \\
(\mathrm{X})\end{array}$ & $\begin{array}{c}\text { Startup } \\
\text { Eco } \\
\text { system }\end{array}$ & $X-X$ & $(X-X)^{2}$ & $Y-Y$ & $(Y-Y)^{2}$ \\
\hline Germany & 4.2 & 12.46 & 0.69 & 0.47 & 2.61 & 6.80 \\
Sweden & 4.05 & 12.77 & 0.54 & 0.29 & 2.92 & 8.51 \\
Belgium & 4.04 & 10.08 & 0.53 & 0,28 & 0.23 & 0.05 \\
Austria & 4.03 & 10.04 & 0.52 & 0.27 & 0.19 & 0.03 \\
Nether- & 4.02 & 12.90 & 0.51 & 0.26 & 3.05 & 9.28 \\
lands & & & & & & \\
Denmark & 3.99 & 10.65 & 0.48 & 0.23 & 0.80 & 0.64 \\
United & 3.99 & 16.71 & 0.48 & 0.23 & 6.86 & 47.02 \\
Kingdom & & & & & & \\
Finland & 3.97 & 11.36 & 0.46 & 0.21 & 1.51 & 2.27 \\
France & 3.84 & 11.45 & 0.33 & 0.11 & 1.60 & 2.55 \\
Spain & 3.83 & 12.39 & 0.32 & 0.10 & 2.54 & 6.44 \\
Italy & 3.74 & 10.06 & 0.23 & 0.05 & 0.21 & 0.04 \\
Czech & 3.68 & 10.16 & 0.17 & 0.03 & 0.31 & 0.09 \\
Republic & & & & & & \\
Portugal & 3.64 & 10.03 & 0.13 & 0.02 & 0.18 & 0.03 \\
Lux em - & 3.63 & 6.98 & 0.12 & 0.01 & -2.87 & 8.25 \\
bourg & & & & & & \\
Poland & 3.54 & 10.44 & 0.03 & 0.00 & 0.59 & 0.34 \\
Ireland & 3.51 & 11.11 & 0.00 & 0.00 & 1.26 & 1.58 \\
Hungary & 3.42 & 9.18 & -0.09 & 0.01 & -0.67 & 0.45 \\
Slovenia & 3.31 & 7.91 & $-\mathbf{0 . 2 0}$ & 0.04 & -1.94 & 3.78 \\
Estonia & 3.31 & 11.26 & -0.20 & 0.04 & 1.41 & 1.98 \\
Greece & 3.2 & 8.82 & -0.31 & 0.10 & -1.03 & 1.07 \\
Cyprus & 3.15 & 4.38 & -0.36 & 0.13 & -5.47 & 29.95 \\
Romania & 3.12 & 9.21 & -0.39 & 0.15 & -0.64 & 0.41 \\
Croatia & 3.1 & 7.56 & -0.41 & 0.17 & -2.29 & 5.26 \\
Bulgaria & 3.03 & 9.26 & -0.48 & 0.23 & -0.59 & 0.35 \\
Slovakia & 3.03 & 7.80 & -0.48 & 0.23 & -2.05 & 4.22 \\
Lithuania & 3.02 & 10.52 & -0.49 & 0.24 & 0.67 & 0.44 \\
Ukraine & 2.83 & 9.72 & -0.68 & 0.47 & -0.13 & 0.02 \\
Malta & 2.81 & 2.06 & -0.70 & 0.49 & -7.79 & 60.73 \\
Latvia & 2.81 & 8.47 & -0.70 & 0.49 & -1.38 & 1.91 \\
I & & & & 5.35 & & 204.51 \\
\hline Source:cal & & & & & \\
\hline
\end{tabular}

Source: calculated by the authors.
Score; and within the significant fluctuations, for the Startup Ecosystem Score, but the data on both indicators can be considered homogeneous and suitable for comparison. The correlation coefficient between the two indicators is 0.65 , i.e. shows a sufficiently tight relationship. The results obtained indicate that there is a direct relationship between the indicators. And in this case, it can be noted that the logistics performance of the country can be not only one of the areas in which startups are developed, but also directly part of the infrastructure of the startup ecosystem.

Oliver Wyman distinguishes five major logistic startup clusters: online platforms, asset management solutions, robotics/autonomous vehicles, shipping execution \& tracking, and data \& analytics solutions. According to Oliver Wyman research, a large \%age of new logistics startups are focused on online platforms and data-driven services - areas that are easily scalable and require little fixed-cost investment. However, rapid technological evolution means that all identified startup clusters are seeing a steady stream of new entrants [2].

At the same time, Supply Chain Media has surveyed and researched 53 startups, all founded in Europe in or since 2012, and positioned them in a matrix containing ten categories of logistics solutions ranging from supplier management right through to home delivery [16].

The authors have divided the EU startups surveyed by Supply Chain Media and the Ukrainian startups by proposed logistic clusters (Fig. 5). The analysis of this distribution has made it possible to determine that the EU startups are repre-

Table 3. Variation Coefficients for LPI and Startup Ecosystem and Correlation Coefficient

\begin{tabular}{|l|c|c|c|c|c|}
\hline \multicolumn{1}{|c|}{$\begin{array}{c}\text { Sample, } \\
n=29\end{array}$} & $\begin{array}{c}\text { Ave- } \\
\text { rage } \\
\text { value }\end{array}$ & $\begin{array}{c}\text { Disper- } \\
\text { sion }\end{array}$ & $\begin{array}{c}\text { The } \\
\text { standard } \\
\text { deviation }\end{array}$ & $\begin{array}{c}\text { The varia- } \\
\text { tion coeffi- } \\
\text { cient, \% }\end{array}$ & $\begin{array}{c}\text { Correla- } \\
\text { tion coef- } \\
\text { ficient, } r\end{array}$ \\
\hline $\begin{array}{l}\text { LPI Score } \\
\text { Startup Eco- } \\
\text { system Score }\end{array}$ & 3.51 & 0.18 & 0.42 & 12 & 0.65 \\
& 9.05 & 2.65 & 26 & \\
\hline
\end{tabular}

Source: calculated by the authors. 


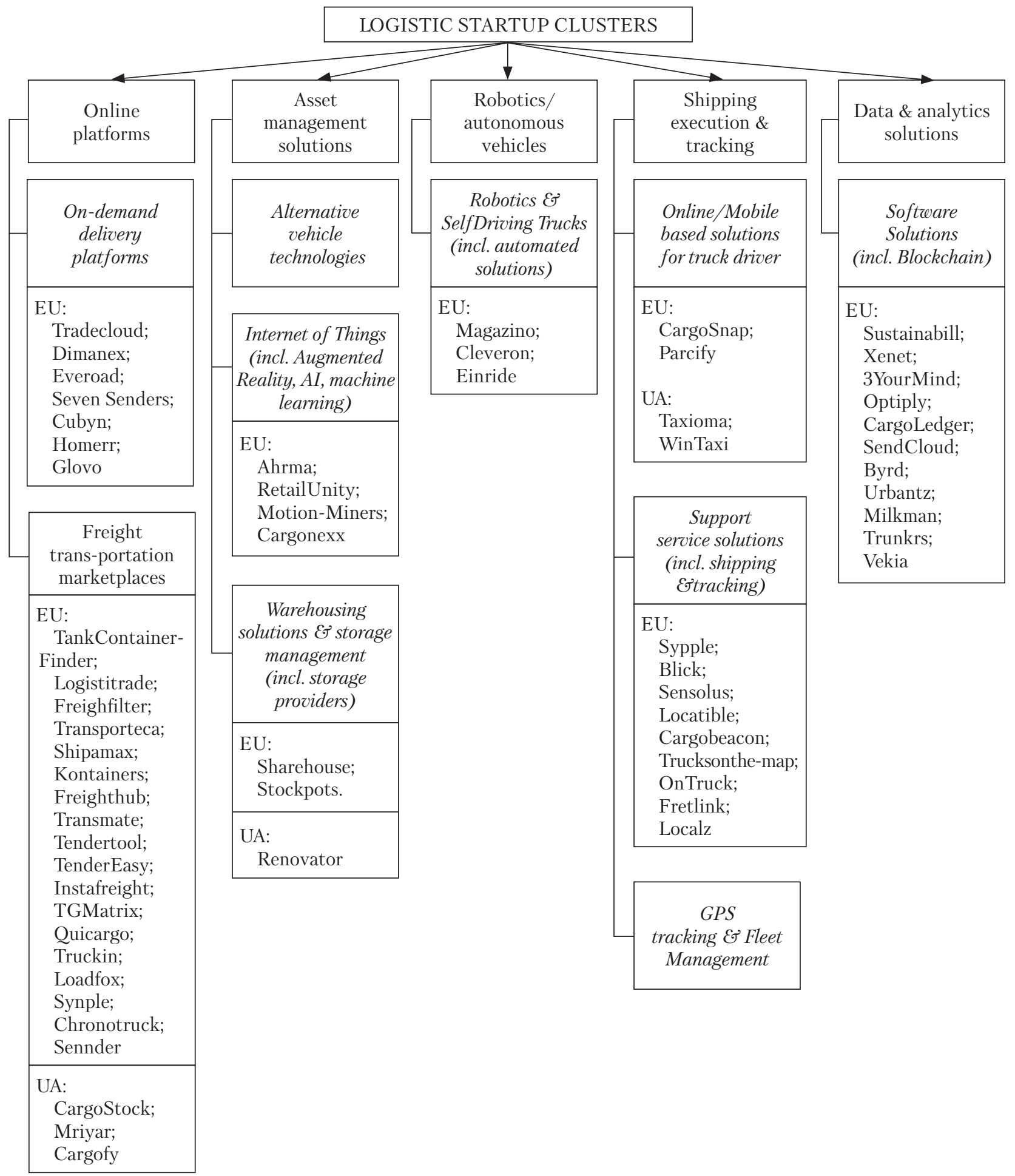

Fig. 5. The EU and Ukrainian logistics and transportation startups distributed by Logistics Startup Clusters Source: developed by the authors on the base of $[2,16]$. 


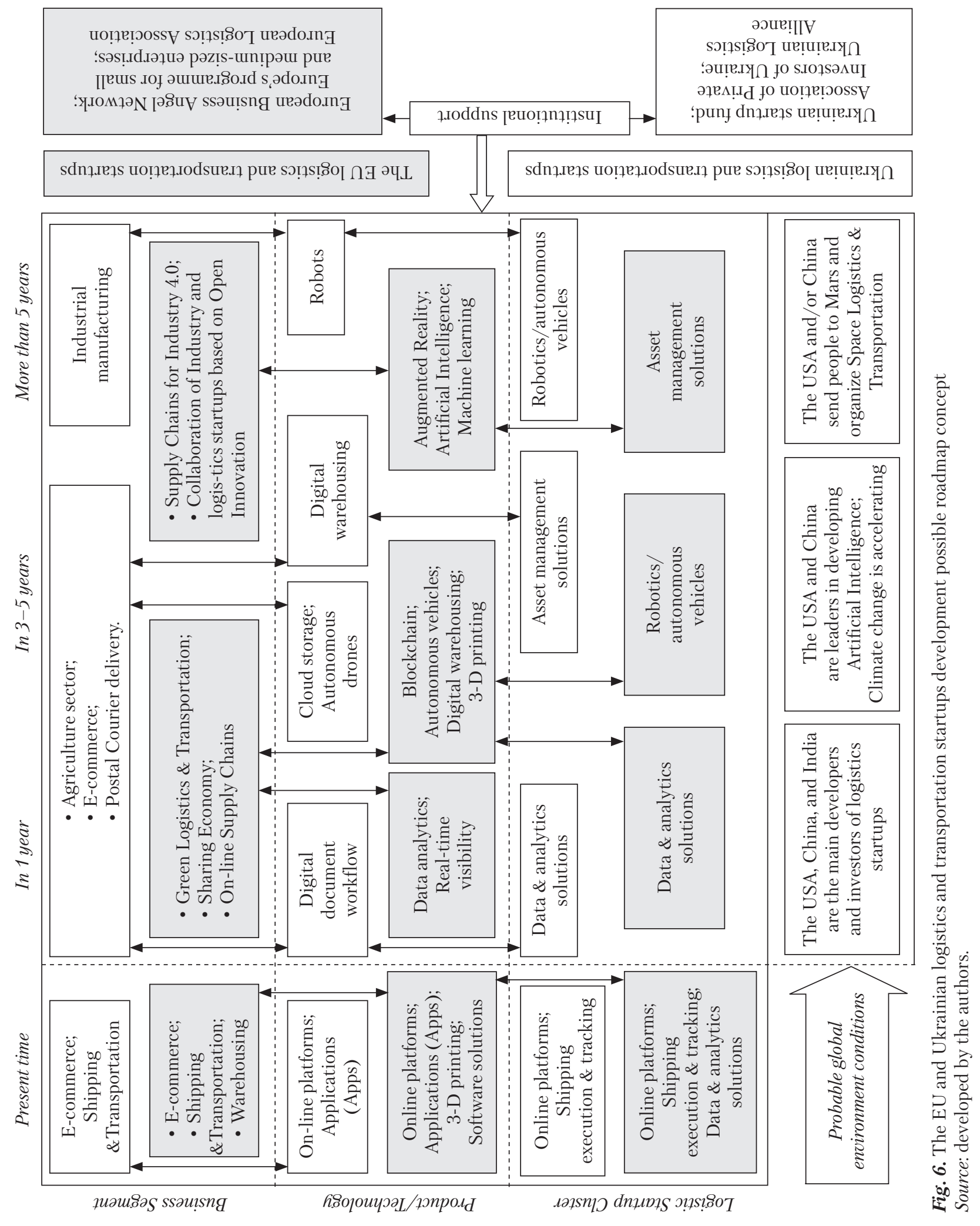

ISSN 2409-9066. Sci. innov. 2027. 17 (2) 
sented in all 5 logistics startup clusters, while Ukrainian startups are located in 3 clusters. However, there is a common imbalance in the distribution of logistics startups by their number in each cluster.

Thus, the EU logistic startups distributed according to the clusters as follows: Online platforms $-45 \%$, Asset management solutions $-10 \%$, Robotics/autonomous vehicles - 5\%, Shipping execution \& tracking $-20 \%$ and Data \& analytics solutions $-20 \%$. Ukrainian startups are also concentrated in the Online platforms cluster $50 \%$ of the total startups in logistics and transportation, in the Shipping execution \& tracking cluster there are $34 \%$ of startups and in Asset management solutions $-16 \%$. It can be said that in the structure of distribution Ukrainian logistics startups and projects of the EU countries have similar development priorities, in particular that the largest number of logistics startups belong to the Online platforms cluster. This is because Online platforms are end-user oriented, userfriendly and relatively inexpensive, easy and fast to develop, and do not require significant investment for implementation. While, for example, building Robots or autonomous vehicles requires a lot of time, previous research and significant investment in both development and implementation and growth.

Having analyzed the current state of startups development, the success of logistics performance, key clusters of logistics startups formation in Ukraine and the EU countries, it is expedient to determine the main directions of development of logistics startups on a long-term perspective. It was formed for this purpose the EU and Ukrainian Logistic Startups Development Roadmap (Fig. 6).

The roadmap is presented in the form of a matrix where the horizontal axis of the top defines the time horizons for the development of logistics startups: current period and prospects in a year, in $3-5$ years and in a period of more than 5 years.

The vertical axis identifies key business segments that anticipate the operation of logistics startups, technology products/technologies that are the key innovative idea of startups, and the clusters of logistics startups in which they will operate. The horizontal axis below outlines the likely key conditions of the global environment in which the development of logistics startups can occur for the appropriate term. And the separate pillar contains the organizations, which provide institutional support for the logistics startups in Ukraine and the EU. The figure shows the characteristics of the development of the EU logistics startups (with dimming) and for the projects from Ukraine (without dimming).

The acceleration of the pace of formation and development of startups in all fields of activity is a testament to the significant acceleration of the development of science and technology in general. Transportation and logistics are not a priority for startup developers in either the EU or Ukraine. However, this area of activity is serviceable and supportive to everyone else, that is, without innovation in logistics and transportation, the pace of development of other industries can even slow down.

This can be confirmed by the correlation analysis performed between countries' ratings of startup ecosystems development and logistics performance index. It was determined the presence of sufficiently tight connection, which indicates a direct relationship between indicators. So, it can be said that the logistics performance of the country can be not only one of the areas in which startups are developed, but also directly part of the infrastructure of the startup ecosystem.

Oliver Wyman's dedicated clusters of logistics startups confirm that all science and technology innovations are being actively implemented in the logistics sector, but countries such as the United States, China, and India are leaders in such projects. As for the EU countries and Ukraine, for the time being, the vast majority of startups ( $45 \%$ and $50 \%$, respectively) operates in a cluster of Online platforms that are relatively inexpensive, easy and fast to develop, and do not require significant investment for implementation. This 
is confirmed by the data on investments in logistics startups, which are estimated as USD 1.5 billion, in the United States; EUR 160 million in the EU; and at most, USD 5 million, in Ukraine. The roadmap for the likely further development of the EU and Ukraine logistics startups has been demonstrating the transition to more knowledgeintensive clusters: Robotics/autonomous vehic- les and Asset management solutions. However, it is difficult to make any accurate predictions, because the external environment is also actively developing and a key direction of its development, in the case of space and other planets exploration may become Space Logistics \& Transportation. This may be the subject of further research in this area.

\section{REFERENCES}

1. Sword, A. (2019). European logistics start-ups to watch in 2019. URL: https://edelivery.net/2019/01/6-european-logistics-start-ups-watch-2019/. (Last accessed: 06.04.2020).

2. Wyman, O. (2017). Velocity Travel Transport Logistics. URL: https://www.oliverwyman.fr/content/dam/oliver-wyman/europe/france/fr/Publications/Velocity_Travel_Transport_Logistics_2017.pdf (Last accessed: 30.10.2019).

3. Wengler, S., Biermann, Ph. (2018). Logistics Startups Are Booming. URL: https://www.simon-kucher.com/tr/blog/logistics-startups-are-booming (Last accessed: 06.04.2020).

4. Khromova, D. D., Antonenko, K. V. (2018). Current world trends in the development of startups on the world stage. Scientific Bulletin of Uzhgorod National University, 19(3), 123-127.

5. Babiachok, R. I., Kulchytskyi, I. I. (2018). The main trends in the development of startups in Ukraine: problems, obstacles and opportunities. URL: https://www.civic-synergy.org.ua/wp-content/uploads/2018/04/Osnovni-tendentsiyirozvytku-startapiv-v-Ukrayini-1-1.pdf (Last accessed: 08.03.2020).

6. Tech ecosystem guide to Ukraine. (2019). 61 p. URL: https://data.unit.city/tech-guide/Tech_Ecosystem_Guide_To_ Ukraine_En-1.1.pdf(Last accessed: 10.02.2020).

7. Blank, S., Dorf, B. (2013). The Startup Owner's Manual; trans. From Eng. Moskow: Alpina Publisher. 616 p.

8. Ries, E. (2011). The Lean Startup: How Today's Entrepreneurs Use Continuous Innovation to Create Radically Successful Businesses. New York: Currency. 336 p.

9. Notes from the AI frontier: Tackling Europe's gap in digital and AI. (2019). McKinsey Global Institute. 60 p.

10. Innovate Europe: Competing for global innovation leadership. (2019). Insight Report. World Economic Forum in collaboration with McKinsey \& Company. 44 p.

11. Innovation in Europe: Changing the game to regain a competitive edge. (2019). McKinsey Global Institute. 28 p.

12. Shifting patterns: The future of the logistics industry.(2016). PwC's future in sight series. 20 p. URL: http://www.pwc. com/futureinsight. (Last accessed: 06.04.2020).

13. EU Startup Monitor. Report. (2018). 36 p. URL: http://startupmonitor.eu/EU-Startup-Monitor-2018-Report-WEB. pdf (Last accessed: 06.04.2020).

14. Einride official web-site. URL: https://www.einride.tech/ (Last accessed: 06.04.2020).

15. StartupBlink Ecosystem Ranking. (2019). URL: https://www.startupblink.com/startups/kiev+ukraine (Last accessed: 30.12.2019).

16. European start-ups secure over EUR160 million of investment capital. (2018). URL: https://www.supplychainmovement.com/european-startups-secure-eur160-million-investment-capital/ (Last accessed: 06.04.2020).

17. Logistics Performance Index. (2018). The World Bank. URL: https://lpi.worldbank.org/international/scorecard (Last accessed: 06.04.2020).

18. Coefficient of variation. URL: https://en.wikipedia.org/wiki/Coefficient_of_variation (Last accessed: 06.02.2020).

Received 20.05.2020

Revised 14.09.2020

Accepted 02.02.2021 
Бояринова, К.О. (https://orcid.org/0000-0001-5879-2213),

Копішинська, К.О. (https://orcid.org/0000-0002-1609-2902)

Національний технічний університет України

«Київський політехнічний інститут імені Ігоря Сікорського»

37, Просп. Перемоги, Київ, Україна, 03056,

+380 44236 7989, mail@kpi.ua

\section{АНАЛІЗ РОЗВИТКУ ЛОГІСТИЧНИХ \\ СТАРТАПІВ У КРАЇНАХ ЄС ТА В УКРАЇНІ}

Вступ. Прискорення технологічного розвитку зумовлює активізацію інноваційного підприємництва в усіх сферах. На сьогодні розвиненість стартап екосистеми в країні відображає ії зацікавленість та сприяння розвитку нових технологій.

Проблематика. Ефективність транспортно-логістичної діяльності демонструє розвиненість інфраструктури країни в цілому та істотно впливає на результативність економічної діяльності. Розроблення та реалізація логістичних стартапів сприяє розв'язанню деяких системних проблем галузі та її подальшому розвитку.

Мета. Аналіз ринку логістичних стартапів країн ЄС та України, визначення напрямів його подальшого розвитку.

Матеріали й методи. Використано загальнонаукові та спеціальні методи: аналізу та синтезу - при визначенні секторальної структури формування та розвитку стартапів країн ЄС та України, кореляційного аналізу - при встановленні залежності між показниками розвитку стартап екосистем та індексів логістичної діяльності країн, групування при розподілі логістичних стартапів країн ЄС та України за кластерами, графічний метод - для розроблення дорожньої карти розвитку логістичних стартапів.

Результати. Досліджено секторальну структуру стартапів країн СС та України, визначено частку транспортно-логістичних проєктів. Проаналізовано рейтинги країн ЄС та України за показниками розвитку стартап екосистем та логістичної діяльності. Кореляційний аналіз виявив сильний зв'язок між рейтингами країн за показниками розвитку стартап екосистем та індексу логістичної діяльності. Розподілено основні логістичні стартапи країн ЄС та України відповідно до певних кластерів логістичних стартапів. Запропоновано дорожню карту розвитку стартапів у сфері логістики та транспортування для країн ЄС та України.

Висновки. На сьогодні логістичні стартапи не $є$ пріоритетним напрямом розвитку ринку ані в країнах $Є \mathrm{C}$, ані в Україні. Проте як для країн $Є С$, так і для України, в майбутньому передбачено розвиток логістичних стартапів у наукомістких кластерах.

Ключові слова: стартапи, логістичні стартапи, індекс логістичної діяльності, стартап екосистема, кластер, дорожня карта. 